University of South Florida

DIGITAL COMMONS

Digital Commons @ University of

@ UNIVERSITY OF SOUTH FLORIDA

South Florida

$1-1-2010$

\title{
2010 Work Plan USF System
}

USF

Follow this and additional works at: https://digitalcommons.usf.edu/usf_accountability_reports

\section{Scholar Commons Citation}

USF, "2010 Work Plan USF System" (2010). USF Accountability Reports. 14.

https://digitalcommons.usf.edu/usf_accountability_reports/14

This Article is brought to you for free and open access by the USF Archives at Digital Commons @ University of South Florida. It has been accepted for inclusion in USF Accountability Reports by an authorized administrator of Digital Commons @ University of South Florida. For more information, please contact digitalcommons@usf.edu. 


\section{University of South Florida System}

\section{Strategic Plan}

The University of South Florida System comprises four institutions: USF Tampa (including USF Health) classified by the Carnegie Foundation in the highest basic category - doctoral granting research university with very high research activity; and the three distinctive master's level campuses of USF St. Petersburg, USF Sarasota-Manatee, and USF Polytechnic. USF Tampa and USF St. Petersburg are separately accredited; the other two, currently accredited with USF Tampa, are in the process of becoming separately accredited consistent with Florida statutes. All four institutions have distinct missions and their own detailed strategic plans approved by the USF Board of Trustees.

The USF System was formed to bring these four institutions together, so that collectively they would serve the region and beyond in optimal ways, resulting in a stronger presence and a distinctiveness that provides a competitive differentiation. In addition to expanding student access and providing a strong and unified voice for higher education, the USF System capitalizes on synergies and economies of scales among its institutions that best serve its students, faculty, staff, alumni, and communities.

The USF System Strategic Plan, the first comprehensive plan for the System, complements the institutional strategic plans and provides a blueprint for the future.

http:/ / system.usf.edu/system-overview/strategic-plan.asp

http://www.sarasota.usf.edu/Administration/CEO/mission.php

http://www.stpete.usf.edu/academics/general_information/mission.htm

http://www.poly.usf.edu/AboutUs/StrategicPlan.html

\section{Mission Statement}

The University of South Florida System (comprised of USF Tampa classified by the Carnegie Foundation in the highest basic category - doctoral granting research university with very high research activity; and the three distinctive master's level campuses of USF St. Petersburg, USF SarasotaManatee, and USF Polytechnic) catalyzes and coordinates initiatives at and among its interdependent institutions that: develop graduates for $21^{\text {st }}$ century careers; advance research, scholarship, and creative endeavors to improve the quality of life; and engage its communities for mutual benefit. 


\section{Overview of Core Institutional Strengths, Special Assets, and Niche Contributions}

The USF System is dedicated to excellence in teaching and learning, research, scholarly and creative activity, along with service and community engagement by enhancing academic opportunities, broadening its global connections, promoting interdisciplinary learning, research and innovation initiatives, and developing strong and sustained community partnerships. Specifically:

\section{Access to and Production of Degrees - Enhanced Opportunities:}

The USF System provides access to an array of university experiences to meet the different needs of its diverse clientele. From the very high research intensive doctoral campus, USF Tampa, to the distinctive master's level campuses of USF St. Petersburg, USF Sarasota-Manatee, and USF Polytechnic, the system offers a range of college experiences in size, mission and residency along with a wide selection of degree programs. Cooperative degree programs, innovative courses, interdisciplinary initiatives and undergraduate and graduate research opportunities, presented across the system, add substantially to undergraduate and graduate student prospects and foster student success. Activities focus on the recruitment and retention of top-level students and highly qualified faculty to enhance learning effectiveness, degree production, improve student retention, and improve graduation rates.

\section{Economic Development - New Job Creation:}

The USF System significantly impacts the Florida economy through its basic and applied research activities (funded through external grants and contracts), business, commercial and hightechnological innovations, new high skilled and high wage job creation, and community engaged scholarship. The development of public-private partnerships facilitates new-found relationships in teaching and research that benefit communities throughout the state and beyond. These partnerships include close ties with Draper Laboratory, SRI International, and the Mote Marine Research Institute. USF is host to the Florida Institute of Oceanography, houses the Florida Center of Excellence for Biomolecular Identification and Targeted Therapeutics (FCoEBITT), and is an active partner in the Florida Energy Systems Consortium (FESC). The USF System promotes synergies among its members, serving as a major economic engine for the region and the state, by challenging its institutions to: increase the production of talented graduates in targeted, high demand fields; increase basic and applied research supported by the private sector and external funding; incubate a significant number of new companies, patents and licensing revenues; and enhance the quality of life through medical breakthroughs.

\section{Global Perspectives, Competitiveness and Impact:}

The USF System has a national and international impact that promotes the state's economic development and helps place it on the global stage. The USF System continues to expand its global activities, international faculty exchanges, recruitment of full fee-paying international students, student education abroad programs, research collaborations, and service learning, thus boosting Florida's international competitiveness and place in the global economy. The USF System advances partnerships with institutions of higher education from around the world providing additional opportunities in teaching and research for students and faculty, as well as preparing globally engaged graduates who compete successfully in the global marketplace of ideas. 
4. World Class Academic Programs and Research Capacity:

Under the basic classification of the Carnegie Foundation, USF Tampa is ranked in the highest category - a Research University with very high research activity (RU/VH) that grants doctoral degrees. As such, USF Tampa is competitive with similarly classified institutions. This high classification of USF Tampa reflects the distinguished quality of the USF System's academic programs and research capacity, and the contribution it makes to the creation of knowledge and technological innovation, in building Florida's new economy. Further adding to the distinguished quality of the USF System's academic programs and research capacity, is the local importance and impact of applied research taking place on the distinctive and mission-driven regional institutions/campuses.

\section{Current Peer Institutions}

\section{USF System Peer Institutions:}

- Rutgers: The State University of New Jersey (3 campuses; all included with the main campus), AAU Member

- University of Pittsburgh (5 member system; all included with the main campus), AAU Member

- Arizona State University (4 member system; all included with the main campus)

- University of Houston (6 member system; 4 are separately accredited)

Each USF System member institution has established its own peer institutions, as appropriate to its mission and vision.

\section{Institutional Vision and Strategic Directions for the Next 5 - 10 Years}

\section{USF SYSTEM VISION}

The University of South Florida System will empower and connect its institutions into a distinctive system, nationally recognized for innovation in its teaching and research, for attracting outstanding and diverse scholars, staff and students, and for transforming its region and beyond.

\section{VALUES}

The University of South Florida System embraces the generally accepted values of higher education, including freedom of inquiry, academic excellence, student success, shared governance, accountability, collegiality, and integrity. It particularly advances the following as hallmark System values:

- Diverse perspectives with a unified vision

- Innovative in approach, entrepreneurial in spirit, and disciplined in action

- Internally collaborative and externally competitive to be "best in class"

- Open and honest communication

- Equitable and fair decision making

- Social, economic, and environmental sustainability

- Exemplary System citizenship, sharing best practices

- Passion for excellence 


\section{GOALS}

\section{Goal 1: Student Success, Access, and Satisfaction}

The USF System will enable access to qualified students and will promote student success throughout the System by supporting activities that result in retention and graduation at higher than predicted rates; employment or admission to graduate or professional schools at desired rates; and lower than average debt loads and higher than average satisfaction when compared to peer institutions.

\section{Goal 2: Research, Economic Impact and Community Engagement}

The USF System will coordinate and promote research and innovation by: providing information and services; creating synergies among faculty across the System; and fostering external partnerships.

These activities will lead to measurable increases in the creation, dissemination, and utilization of new knowledge. In addition, the USF System will coordinate the activities and promote synergies among its institutions to serve as a major economic engine for the region and state by challenging its institutions to: increase the production of graduates in high demand fields; increase applied research supported by the private sector; and incubate a significant number of new companies, agencies, and occupations.

The USF System will also challenge its institutions to increase further their level of community engagement, by sharing best practices, supporting their applications to achieve the Carnegie "Community Engaged" designation, and facilitating increased collaborations among institutions and across the region. For its leadership in strengthening the economy and community engagement, the USF System will be recognized as the key unifying element for the region.

\section{Goal 3: Academic and Administrative Collaborations}

The USF System will provide the leadership to increase academic and administrative collaborations among the institutions by establishing pipelines for students to graduate and professional programs; by the creation of joint degree programs and innovative cross-institution curricula; by promoting joint research activities and other faculty development opportunities; by improving the efficiency, effectiveness, and functionality of identified System-wide administrative processes; and by measuring the continuous improvement of those services, including increased user satisfaction.

To ensure efficient and effective operations at all USF regional institutions/campuses, to minimize unnecessary duplication of effort, to provide fiscal oversight and financial stewardship, and to reap any economies of scale, the USF System will develop and maintain integrated, system-wide functions. USF System-wide administrative functions include:

1. Academic planning liaison to the Board of Governors;

2. Diversity and Equal Opportunity;

3. Government Relations;

4. General Counsel;

5. Audit and Compliance;

6. Administrative Services including purchasing, human resources, financial and accounting systems, enterprise business systems for student, financial and employee data, payroll, and related monitoring and compliance services;

7. Treasury and accounting, including debt management, investments, external financial reporting, banking, accounts payable, and travel processing;

8. Research and Innovation including compliance over all research activities;

9. Collective Bargaining;

10. NCAA Intercollegiate Athletics;

11. USF Libraries with the exception of USF St. Petersburg; 
12. Financial Aid;

13. International Affairs for all international programs across USF institutions and campuses;

14. Decision Support, the official data repository, in collaboration with the Offices of University Budgets, Comptroller, and Enterprise Business Systems, for data verification and reporting to state and federal agencies;

15. University Advancement (Central Development expertise in the areas of Planned Giving, Corporate and Foundation Relations, Annual Fund, and Advancement Services: Prospect management, Research, Gift processing, Stewardship programs, and Development communication and special events support), the Alumni Association, and the USF Foundation Business Services and Asset Management);

16. Information Technology;

17. System-wide Communications and Marketing including ownership and use of USF names, marks and logos;

18. Regional Accreditation coordination through a designated system representative;

19. Public Safety and Emergency Response; and

20. Environmental health and safety.

Goal 4: Communicating and Branding

The USF System will launch an initiative to develop and then communicate a shared understanding of the USF System's common identity and its relationship to the unique missions and distinctive identities of its member institutions for both internal and external audiences.

\section{Goal 5: Resources}

The USF System will expand and diversify its resource base to increase the financial sustainability of its member institutions so that they can meet their unique missions. The USF System will, in partnership with its member institutions: increase its endowment; its annual giving levels; its research grants and contracts; its revenues from auxiliaries and Direct Service Organizations; and its overall efficiency (especially through optimizing economies of scale). It will also, in partnership with the leadership of its institutions, work with Florida's legislature to increase investment in higher education and to expand the fiscal flexibility of the USF System and its member institutions.

\section{STRATEGIC DIRECTIONS}

The USF System offers a range of rewarding opportunities as each campus develops its particular niche under the umbrella of the USF System and seeks out its relevant and appropriate Carnegie basic classification (from RU/VH - Research Universities, very high research activity at USF Tampa, to the Master's Level - Master's Colleges and Universities, at USF St. Petersburg, USF Sarasota-Manatee, and USF Polytechnic). Strategically, the USF System focuses on:

Providing access to an array of high quality, globally competitive degree programs.

The USF System incorporates diversity in all aspects of its mission: in student teaching and learning opportunities, in degrees offered and awarded, in research and creative scholarly endeavors, as well as in the gender, race, ethnic and socio-economic status of its student body. In response to the diverse nature of all aspects of its mission, the USF system provides an array of graduate and undergraduate degree programs, facilitated by the differentiation of mission and niche contributions specific to each of the four USF System member institutions. At the same time, quality assurance across the system is maintained to avoid unnecessary duplication of programs. 
The USF System is strategically shifting undergraduate enrollment to its regional institutions/campuses as part of the university's plan to expand access in line with the particular missions of each campus. USF St. Petersburg, the only regional institution/campus that currently admits freshmen, enrolled 417 new freshmen in Fall 2009, an increase of 21 percent from the previous year's freshman class. Total undergraduate degree seeking student enrollment rose from Fall 2008 to Fall 2009 by 1.7 percent at USF Tampa; 7.1 percent at USF St. Petersburg; and 8.5 percent at USF Polytechnic. Pointedly, the USF System remains one of the nation's top destinations for transfer students, even with enhanced admission standards for transfer students. Historically, the USF System enrolls many students transferring from the Florida's state public community colleges, demonstrating its commitment to supporting Florida's ' $2+2$ ' system.

The diversity of USF System graduates is evident by the number of graduating students of varying race, ethnic and socio-economic backgrounds. Of the total baccalaureate degrees awarded, approximately $38 \%$ were awarded to PELL recipients, $12 \%$ were awarded to Hispanics, and $12 \%$ awarded to Black, Non-Hispanics in 2008-09. Between 2004-05 and 2008-09, the USF System experienced a $30 \%$ increase in the number of baccalaureate degrees awarded to PELL recipients, a $63 \%$ increase in the number of baccalaureate degrees awarded to Hispanic students, and a $52 \%$ increase in the number of baccalaureate degrees awarded to Black, Non-Hispanic students .

\section{Stimulating the innovation and knowledge-based economy in Florida}

Aligned with the vision of the New Florida initiative for the State of Florida of creating a new state economy based on knowledge and innovation, the USF System stimulates innovation and the knowledge-based economy in Florida through (i) recruitment, development and retention of highly talented faculty and students; (ii) development of externally funded, basic and applied research leading to economic growth and new job creation; (iii) public-private partnerships that attract new companies and venture capital.

Research firmly bonds the university with its constituents through: service, outreach and engagement activities; the corporate community by means of patenting and licensing of technology and targeted research; with other academics through collaborative and cooperative programs; and globally through relationships with research colleagues. Research also connects the system through multidisciplinary approaches to pervasive social, economic, environmental, and health problems. Research provides opportunities to graduate and undergraduate students and prepares them for success in their chosen fields, for entering the workforce, or for progression to graduate and professional education.

\section{Meeting distinctive needs}

The USF System meets the distinctive needs of the region, state, and nation, and has a significant global impact, through its world-class educational programs and top quality research in the life sciences, water resources and sustainability, energy and health. Its basic and applied research activities seek to resolve complex economic, social, environmental, and health problems.

\section{Education:}

The USF System continues to prepare the nation's next generation of leaders, thinkers and scientists by replenishing the ranks of the professoriate for American higher education and placing its graduates in competitive professional programs.

At the undergraduate level, positive trends are noted in baccalaureate degree production in areas of strategic emphasis identified at the state level (e.g., Education, Health Professions, STEM fields). Total undergraduate degrees in all areas of strategic emphasis increased 30\% between 2004-05 and 2008-09, with areas in the Health Professions and STEM programs increasing close to $40 \%$.

At the graduate level, impressive trends can be seen with regard to the number of doctoral degrees 
awarded at USF Tampa, a measure of USF's growing commitment to graduate education and the creation of new knowledge through research, scholarship and creative activity. In addition, ongoing growth in master's level programs across the system, especially in the professions, supports and enhances Florida's economy. In the areas of strategic emphasis identified at the state level (e.g., Education, Health Professions, STEM fields), graduate degree production has also steadily increased. Between 2004-05 and 2008-09 total graduate degrees in all areas of strategic emphasis increased by 18\%, with Education programs increasing $40 \%$ and areas in the Health Professions increasing by nearly $30 \%$ during the same time frame.

\section{Research:}

The USF System maintains research as the centerpiece of the university's strategic plan; it is fundamental to the recruitment and retention of talented faculty and students, and gives the university distinction. The system is focused on five main strategic priorities: student success, research and innovation, community engagement, global literacy and impact, and integrated, interdisciplinary inquiry. The USF System has four internationally recognized research themes: sustainable healthy communities, integrated neurosciences, diabetes and autoimmune disorders, and drug design, development and delivery. Home to Florida's second public medical school, USF's focus on health education and research is a hallmark of the USF System's unique contributions to improving health care in Florida and across the nation.

With a 213\% increase between 2000 and 2007, no other American university grew its federal research enterprise at a faster rate than the USF System, according to the Chronicle of Higher Education's 200910 Almanac. The latest data (2008) from the National Science Foundation (NSF) show USF ranked 43rd for total research expenditures and $36^{\text {th }}$ for federal expenditures compared with all public higher educational institutions in the country.

In addition to its research enterprise, the USF System research and innovation infrastructure is becoming increasingly robust evident by the increasing number of postdoctoral fellows $(120 \%$ increase between 2004-05 and 2008-09) and non-faculty researchers with doctorates (762\% increase between 2004-05 and 2008-09).

\section{Global:}

The USF System continues to work with existing partners and forge new global collaborations under the centerpiece of USF World and the Patel Center for Global Solutions. Major initiatives include the Confucius Institute, the Center for India Studies, the Japan Outreach Initiative, the Institute for the Study of Latin America and the Caribbean, and the Center for the Study of International Languages and Culture. In addition, the Global Academic Partnership (GAP) program facilitates strategic collaborative educational and research opportunities between USF and five major institutions in China, Ghana and the United Kingdom (partnerships in Latin America, the Middle East and India to be developed). In addition, there are many other ongoing specialized partnerships with academic institutions around the world, identified by USF World.

Aspirational Peer Institutions (aspire and plan to be comparable to in the next 5 - 10 years)

- University of Michigan (3 member system; all separately accredited), AAU member

- University of Minnesota (4 member system; all separately accredited), AAU member

- The Ohio State University (6 member system; 1 separately accredited), AAU member

- University of Washington (3 member system; all included with the main campus), AAU member Each USF System member institution has established its own peer institutions, as appropriate to its mission and vision. 


\begin{tabular}{|c|c|c|c|c|c|c|}
\hline \multicolumn{7}{|c|}{ Projected Institutional Contributions to System-Level Goals } \\
\hline \multicolumn{7}{|c|}{ NUMERIC TARGETS } \\
\hline Dashboard Metric & Date & \multicolumn{2}{|c|}{ Actual Value } & Date & \multicolumn{2}{|c|}{ Projected Value } \\
\hline Baccalaureate Degrees Awarded & $2008-09$ & \multicolumn{2}{|c|}{7,479} & $2012-13$ & \multicolumn{2}{|c|}{8,270} \\
\hline Master's Degrees Awarded & $2008-09$ & \multicolumn{2}{|c|}{2,482} & $2012-13$ & \multicolumn{2}{|c|}{2,747} \\
\hline $\begin{array}{l}\text { Research and Professional Doctorates } \\
\text { Awarded }\end{array}$ & 2008-09 & \multicolumn{2}{|c|}{402} & 2012-13 & \multicolumn{2}{|r|}{488} \\
\hline $\begin{array}{l}\text { Federal Academic Research and } \\
\text { Development Expenditures }\end{array}$ & 2007-08 & \multicolumn{2}{|c|}{$\$ 189,282$} & 2011-12 & \multicolumn{2}{|c|}{$\$ 202,578$} \\
\hline $\begin{array}{l}\text { Total Academic Research and } \\
\text { Development Expenditure }\end{array}$ & 2007-08 & \multicolumn{2}{|c|}{$\$ 342,665$} & 2011-12 & \multicolumn{2}{|c|}{$\$ 363,533$} \\
\hline \multirow{2}{*}{$\begin{array}{l}\text { FTIC }^{* * *} \text { Six-Year Retention and } \\
\text { Graduate Rates from the Same IHE }\end{array}$} & \multirow{2}{*}{$\begin{array}{l}2003-09 \\
\text { FTIC } \\
\text { Cohort }\end{array}$} & \multicolumn{2}{|c|}{ Graduated $46.9 \%$} & \multirow{2}{*}{$\begin{array}{l}2007-13 \\
\text { FTIC } \\
\text { Cohort }\end{array}$} & \multicolumn{2}{|c|}{ Graduated $49.9 \%$} \\
\hline & & \multicolumn{2}{|c|}{ Still Enrolled 11.0\% } & & \multicolumn{2}{|c|}{ Still Enrolled 12\% } \\
\hline \multirow{2}{*}{$\begin{array}{c}\text { AA Transfer*** Four-Year Retention } \\
\text { and Graduation Rates from the } \\
\text { Same IHE }\end{array}$} & \multirow{2}{*}{$\begin{array}{l}2005-09 \\
\text { AAT } \\
\text { Cohort }\end{array}$} & \multicolumn{2}{|c|}{ Graduated $62.8 \%$} & \multirow{2}{*}{$\begin{array}{c}2009-13 \\
\text { AAT } \\
\text { Cohort }\end{array}$} & \multicolumn{2}{|c|}{ Graduated $64.8 \%$} \\
\hline & & \multicolumn{2}{|c|}{ Still Enrolled 12.7\% } & & \multicolumn{2}{|c|}{ Still Enrolled 13.7\% } \\
\hline \multicolumn{7}{|c|}{ DIRECTIONAL TARGETS [Indicate Direction: I=Increase, M=Maintain, D=Decrease] } \\
\hline Dashboard Metric & Date & \multicolumn{2}{|c|}{ Actual Value } & Date & Project & Direction** \\
\hline Baccalaureate Degrees Awarded to & sone 00 & \# & $\%^{*}$ & 201212 & \# & $\%^{*}$ \\
\hline Black, Non-Hispanics & 2008-09 & 899 & $12.4 \%$ & $2012-13$ & $\mathbf{I}$ & $\mathbf{I}$ \\
\hline Baccalaureate Degrees Awarded to & & \# & $\%$ * & & \# & $\%$ * \\
\hline Hispanics & $2008-09$ & 875 & $12.1 \%$ & $2012-13$ & $\mathbf{I}$ & $\mathbf{I}$ \\
\hline Baccalaureate Degrees Awarded to & 2008_-09 & $\#$ & $\%$ * & $2012-13$ & \# & $\%{ }^{*}$ \\
\hline Pell Recipients & $2008-09$ & 2,770 & $37.7 \%$ & $2012-13$ & $\mathbf{M}$ & $\mathbf{M}$ \\
\hline Degrees Awarded in Specified & 200809 & Bacc. & Grad. & $2012-13$ & Bacc. & Grad. \\
\hline STEM Fields & $2008-09$ & 1,395 & 530 & $2012-13$ & $\mathbf{I}$ & $\mathbf{I}$ \\
\hline Degrees Awarded in Specified & & Bacc. & Grad. & & Bacc. & Grad. \\
\hline $\begin{array}{l}\text { Health Profession Critical Need } \\
\text { Areas }\end{array}$ & $2008-09$ & 435 & 506 & $2012-13$ & I & $\mathbf{I}$ \\
\hline Degrees Awarded in Specified & 200809 & Bacc. & Grad. & 201213 & Bacc. & Grad. \\
\hline Education Critical Need Areas & $2008-09$ & 112 & 222 & $2012-13$ & I & I \\
\hline $\begin{array}{c}\text { NCLEX Pass Rate for First-Time } \\
\text { Test Takers in Baccalaureate } \\
\text { Nursing Program }\end{array}$ & 2008 & & & 2012 & & $\mathbf{M}$ \\
\hline Licensing Income & 2007-08 & $\$ 1,8$ & 000 & $2011-12$ & & $\mathbf{I}$ \\
\hline Licenses and Options Executed & 2007-08 & & & 2011-12 & & $\mathbf{I}$ \\
\hline Other Transfer ${ }^{* * *}$ Five-Year & 2004-09 & Gradua & $55.6 \%$ & $2008-13$ & Gra & uated \\
\hline $\begin{array}{l}\text { Retention and Graduation Rates } \\
\text { from the Same IHE }\end{array}$ & $\begin{array}{l}\text { Other } \\
\text { Cohort }\end{array}$ & Still Enr & ed $6.7 \%$ & $\begin{array}{l}\text { Other } \\
\text { Cohort }\end{array}$ & Still & rolled \\
\hline
\end{tabular}

"Actual Value" should equal related value in 2009 Annual Report.

* Percentage of Total Baccalaureates Awarded That Were Awarded to Specific Group.

** Projected Direction = INCREASE, MAINTAIN, or DECREASE. 


\section{Additional Primary Institutional Goals/Metrics for the Next One to Three Years}

(In the context of the institutional strategic plan and vision, as well as System priorities, present a minimum of three additional goals on which university effort will be focused in the next one to three years. Describe each goal, including whether the goal is new or continuing, the strategy for achieving that goal, the metrics by which success will be measured, specific actions to be taken in this fiscal year, expected outcomes, and assumptions, including financial, upon which the projected outcomes are predicated.)

\section{Accreditation:}

The USF System will ensure that all its member institutions are accredited by the Southern Association of Colleges and Schools. USF Tampa and USF St. Petersburg are separately accredited while USF SarasotaManatee has submitted an application for separate accreditation. All member institutions of the USF System will be separately accredited by 2012.

Separate accreditation was mandated under Florida Statute Title XLVIII, K-20 Education Code: Chapter 1004.33 The University of South Florida St. Petersburg; Chapter 1004.34 The University of South Florida Sarasota/Manatee; Chapter 1004,345 The University of South Florida Polytechnic.

\section{Student Success - Reshaping the Student Profile:}

A fundamental and ongoing initiative of the USF System is student success; USF focuses on the recruitment of academically talented students, on increasing retention rates and on reducing time to graduation. The goal is to develop talented, technologically skilled and well-educated graduates who are competitively placed to enter top quality graduate schools, professional programs or become highly productive members of the work-force. Data continue to be collected to measure and track student success (e.g., measures of college preparedness, retention and graduation rates, time-to-graduation, degrees awarded).

The USF System is strategically shifting undergraduate enrollment to its regional institutions/campuses as part of the university's plan to expand access in line with the particular missions of each campus. USF Tampa's undergraduate enrollment will be held relatively stable as undergraduate education is aligned more with USF St. Petersburg, USF Sarasota-Manatee and USF Polytechnic. USF St. Petersburg is the only regional institution/campus that currently admits freshmen, although USF Sarasota-Manatee and USF Polytechnic intend to pursue four-year programs to include freshman and sophomores in the next three years. This will increase undergraduate teaching and learning opportunities across the system, through expanded integrated, interdisciplinary initiatives and global activities. Data on undergraduate enrollment and retention are regularly collected (e.g., specific cohort retention and graduation rates, admit yield rates, enrollment rates).

The USF System is strengthening its graduate programs focusing on doctoral research programs at USF Tampa and master's level on all campuses. At the graduate level, impressive trends can be seen with regard to the number of doctoral degrees awarded, a measure of USF's growing commitment to graduate education and the creation of new knowledge through research and creative scholarship. Continuing this trend prepares the nation's next generation of leaders, thinkers and scientists by replenishing the ranks of the professoriate for American higher education and developing a highly skilled workforce. 


\section{Revenue Enhancement/Diversification and Infrastructure:}

The USF System will continue its revenue enhancement initiatives through the development of external funding, private giving, technology transfer and public-private partnerships. The USF System will continue to sponsor research and creative scholarship activities to support external funding awards, patents issued, technology transfer and licensing revenues, and start-up companies formed; it will champion endowment support; and it will continue to foster partnerships such as those with SRI International and Draper Laboratory.

The USF System will develop its infrastructure and continue to add buildings (instructional, research and clinical facilities, and student support) where appropriate to enhance the various missions of its member institutions and growing undergraduate student body especially on the St. Petersburg, Sarasota-Manatee and Polytechnic campuses. Building will also continue in line with the goals of individual USF System member institutions, such as enhancing global initiatives, providing technological opportunities and addressing community engaged scholarship. 
New Academic Degree Program Proposals - Next Three Years (Program development goals need to align with the institutional strategic plan and System priorities.)

\begin{tabular}{|c|c|c|c|c|}
\hline \multicolumn{5}{|l|}{ USF TAMPA } \\
\hline $\begin{array}{l}\text { Proposed Date of } \\
\text { Submission to } \\
\text { University Board } \\
\text { of Trustees }\end{array}$ & $\begin{array}{c}\text { Program } \\
\text { Level } \\
(\mathrm{B}, \mathrm{M}, \mathrm{D})\end{array}$ & $\begin{array}{l}\text { 6-Digit } \\
\text { CIP } \\
\text { Code }\end{array}$ & $\begin{array}{c}\text { Program Title or Degree } \\
\text { Designation }\end{array}$ & $\begin{array}{c}\text { Comments } \\
\text { (Including Proposed Implementation } \\
\text { Date) }\end{array}$ \\
\hline \multicolumn{5}{|c|}{ College of Arts and Sciences } \\
\hline TBD & $\mathrm{D}$ & 25.0101 & $\begin{array}{l}\text { Library and Information } \\
\text { Sciences }\end{array}$ & \\
\hline TBD & $\mathrm{D}$ & 26.0400 & $\begin{array}{l}\text { Cell and Molecular } \\
\text { Biology }\end{array}$ & \\
\hline TBD & $\mathrm{D}$ & 26.1399 & $\begin{array}{l}\text { Ecology, Evolution } \\
\text { Systematics and } \\
\text { Population Biology }\end{array}$ & \\
\hline TBD & M & 45.0701 & $\begin{array}{l}\text { Geographic Information } \\
\text { Systems }\end{array}$ & \\
\hline Fall 2010 & B & 51.0000 & Health Science & Spring 2011 \\
\hline
\end{tabular}

College of Behavioral and Community Sciences

\begin{tabular}{|c|c|c|c|c|}
\hline 2011-2012 & $\mathrm{M}$ & 30.1101 & $\begin{array}{l}\text { 5-Year Masters of } \\
\text { Gerontology }\end{array}$ & $\begin{array}{l}\text { Will provide opportunity for outstanding } \\
\text { undergraduate Gerontology students to } \\
\text { complete the MA with } 1 \text { additional year } \\
\text { enrollment }\end{array}$ \\
\hline Spring 2011 & $\mathrm{M}$ & 51.0201 & $\begin{array}{l}\text { Master's of Science } \\
\text { Degree in Speech- } \\
\text { Language-Hearing } \\
\text { Sciences }\end{array}$ & $\begin{array}{l}\text { Fall 2012; CSD currently offers a PhD which } \\
\text { requires completion of a master's degree prior } \\
\text { to admission. We have had numerous } \\
\text { applicants select other Universities due to this } \\
\text { requirement. We need to develop an enroot } \\
\text { "non-clinical" master's degree in order to accept } \\
\text { students directly into the PhD program from a } \\
\text { bachelor's program }\end{array}$ \\
\hline TBD & $\mathrm{M}$ & 51.0718 & $\begin{array}{l}\text { Long-Term Care } \\
\text { Administration }\end{array}$ & $\begin{array}{l}\text { Based on our BS in LTC Administration, this } \\
\text { program would prepare administrators who } \\
\text { already have a relevant bachelors degree }\end{array}$ \\
\hline TBD & $\mathrm{M}$ & 52.0299 & $\begin{array}{l}\text { Management of Health } \\
\text { and Aging Programs }\end{array}$ & $\begin{array}{l}\text { Possibly offered as a joint program with Public } \\
\text { Health and/or Business }\end{array}$ \\
\hline TBD & $\mathrm{D}$ & $x x \cdot x \times x x$ & $\begin{array}{l}\text { Ph.D. in Applied } \\
\text { Behavior Analysis }\end{array}$ & Pre-proposal to GECC fall 2009 \\
\hline \multicolumn{5}{|c|}{ College of Education } \\
\hline TBD & M & 13.0901 & Educational Studies & Pre-proposal 3/10 \\
\hline TBD & $\mathrm{M}$ & 31.0505 & Exercise Science & Pre-proposal 4/10 \\
\hline 2010-2011 & $\mathrm{M}$ & $x x \cdot x \times x x$ & $\begin{array}{l}\text { MA in Autism Spectrum } \\
\text { Disorders and Severe } \\
\text { Intellectual Disabilities }\end{array}$ & Pre-proposal to GECC 4/2010 \\
\hline
\end{tabular}


College of Medicine

\begin{tabular}{|c|c|c|c|c|}
\hline 2012 & M & 5.2099 & Pharmaceutical Sciences & 2012 \\
\hline 2012 & M & 23.1303 & $\begin{array}{l}\text { Biomedical } \\
\text { Communication \& } \\
\text { Marketing }\end{array}$ & 2012 \\
\hline 2012 & $\mathrm{D}$ & 26.0608 & $\begin{array}{l}\text { Integrated } \\
\text { Neurosciences }\end{array}$ & 2013 \\
\hline 2011 & M & 26.0907 & $\begin{array}{l}\text { Diabetes \& Autoimmune } \\
\text { Diseases }\end{array}$ & 2011 \\
\hline 2011 & M & 30.2401 & $\begin{array}{l}\text { Behavioral } \\
\text { Neurosciences }\end{array}$ & 2011 \\
\hline 2012 & M & 51.0701 & Healthcare Management & 2013 \\
\hline 2012 & M & 51.0912 & Physician's Assistant & 2012 \\
\hline 2011 & M & 51.2706 & Health Informatics & 2011 \\
\hline 2012 & M & 51.3102 & Clinical Nutrition & 2012 \\
\hline 2013 & $\mathrm{D}$ & 51.9999 & Infectious Diseases & 2013 \\
\hline 2011 & $\mathrm{D}$ & $x x \cdot x x x x$ & $\begin{array}{l}\text { Rehabilitation Sciences } \\
\text { (Interdisciplinary) }\end{array}$ & 2012 \\
\hline \multicolumn{5}{|c|}{ College of The Arts } \\
\hline 2013 & $\mathrm{D}$ & 50.0703 & Art History & \\
\hline 2011 & M & 50.0704 & Arts Management & Interdisciplinary with The College of Business \\
\hline 2013 & M & $x x \cdot x \times x x$ & Museum Studies & \\
\hline
\end{tabular}

* Under review by the BOG June 2010 


\begin{tabular}{|c|c|c|c|c|}
\hline \multicolumn{5}{|c|}{ USF ST. PETERSBURG } \\
\hline $\begin{array}{l}\text { Proposed Date of } \\
\text { Submission to } \\
\text { University Board } \\
\text { of Trustees }\end{array}$ & $\begin{array}{c}\text { Program } \\
\text { Level } \\
(\mathrm{B}, \mathrm{M}, \mathrm{D})\end{array}$ & $\begin{array}{l}\text { 6-Digit } \\
\text { CIP } \\
\text { Code }\end{array}$ & $\begin{array}{l}\text { Program Title or } \\
\text { Degree Designation }\end{array}$ & $\begin{array}{c}\text { Comments } \\
\text { (Including Proposed Implementation } \\
\text { Date) }\end{array}$ \\
\hline \multicolumn{5}{|c|}{ College of Arts and Sciences } \\
\hline 2010-2011 & M & 09.0702 & $\begin{array}{l}\text { M.S. in Digital Media } \\
\text { (online) }\end{array}$ & $\begin{array}{l}\text { Builds on the strengths of existing faculty and } \\
\text { current MA in Journalism and Media Studies, } \\
\text { also reaching a new online audience. Initial } \\
\text { enrollment planned for Fall 2012. USFSP: 1.3; } \\
\text { BOG Critical Needs Designation }\end{array}$ \\
\hline 2011-2012 & B & 26.0101 & B.S. in Biology & $\begin{array}{l}\text { Strong student demand for this degree. Initial } \\
\text { enrollment planned in Fall 2012. USFSP: 1.2; } \\
\text { BOG Critical Needs Designation }\end{array}$ \\
\hline $2012-2013$ & B & 40.0607 & $\begin{array}{l}\text { B.S. in Marine Science } \\
\text { CIP code is for } \\
\text { Oceanography }\end{array}$ & $\begin{array}{l}\text { Builds on current B.S. in Environmental Science. } \\
\text { Initial enrollment planned in Fall 2014. USFSP: } \\
\text { 4.2; BOG Critical Needs Designation }\end{array}$ \\
\hline 2013-2014 & M & 42.0101 & M.S. in Psychology & $\begin{array}{l}\text { Builds on strong B.A. in Psychology and faculty } \\
\text { strength in infant/family mental health and } \\
\text { learning disorders. Initial enrollment planned } \\
\text { for Fall 2013. USFSP: 4.3; BOG Area of } \\
\text { Strategic Emphasis }\end{array}$ \\
\hline $2013-2014$ & M & 43.0111 & $\begin{array}{l}\text { MS in Forensic } \\
\text { Computing, Security } \\
\text { and Networking }\end{array}$ & $\begin{array}{l}\text { Joint program with College of Business and } \\
\text { College of Arts and Sciences (e.g., Political } \\
\text { Science, GIS and Criminology). Admitting } \\
\text { students in Fall 2014. USFSP: 1.5; BOG Critical } \\
\text { Needs Designation }\end{array}$ \\
\hline 2011-2012 & B & 45.0702 & $\begin{array}{l}\text { B.S. in Geospatial } \\
\text { Sciences } \\
\text { This CIP code is for } \\
\text { Cartography }\end{array}$ & $\begin{array}{l}\text { New field that has a multitude of applications. } \\
\text { Initial enrollment planned in Fall 2012. USFSP: } \\
\text { 1.3; BOG Area of Strategic Emphasis }\end{array}$ \\
\hline $2012-2013$ & B & 50.0702 & B.A. in Studio Art & $\begin{array}{l}\text { Builds on current BFA in Graphic Design. } \\
\text { Initial enrollment planned in Fall 2013. USFSP: } \\
\text { 4.3; BOG Area of Strategic Emphasis }\end{array}$ \\
\hline $2012-2013$ & B & 50.0703 & B.A. in Art History & $\begin{array}{l}\text { Builds on current BFA in Graphic Design and } \\
\text { meets community need. Initial enrollment } \\
\text { planned in Fall 2013. USFSP: 4.3; BOG Area of } \\
\text { Strategic Emphasis }\end{array}$ \\
\hline $2010-2011$ & B & 51.0000 & B.S. in Health Sciences & $\begin{array}{l}\text { Joint program with the College of Business and } \\
\text { College of Arts and Sciences. Initial enrollment } \\
\text { planned for Fall 2010. USFSP: 1.2; BOG Area of } \\
\text { Strategic Emphasis }\end{array}$ \\
\hline 2011-2012 & B & 51.1601 & B.S. in Nursing & $\begin{array}{l}\text { Program for RN's only for completion of the } \\
\text { BSN. Initial enrollment planned for Fall } 2012 . \\
\text { USFSP: 1.3; } \\
\text { BOG Critical Needs Designation }\end{array}$ \\
\hline
\end{tabular}


College of Business

\begin{tabular}{|l|l|l|l|l|}
\hline 2012-2013 & M & 51.0000 & M.S. in Health Sciences & $\begin{array}{l}\text { Joint program with College of Arts and } \\
\text { Sciences; College of Business would host health } \\
\text { economics track. Admitting students in Fall } \\
\text { 2013. USFSP: 1.2; BOG Critical Needs } \\
\text { Designation }\end{array}$ \\
\hline $2010-2011$ & B & 52.0201 & $\begin{array}{l}\text { Entrepreneurship and } \\
\text { Innovation }\end{array}$ & $\begin{array}{l}\text { Focus on those undergraduate students with a } \\
\text { career aspiration to self-venture and/or that } \\
\text { may work in a small business. Initial enrollment } \\
\text { planned for Fall 2010. USFSP: 1.2; BOG Area of } \\
\text { Strategic Emphasis }\end{array}$ \\
\hline $2012-2013$ & M & 52.0206 & $\begin{array}{l}\text { M.S. in Non-Profit } \\
\text { Leadership and } \\
\text { Management }\end{array}$ & $\begin{array}{l}\text { Joint program with College of Business and } \\
\text { College of Arts and Sciences. Admitting } \\
\text { students in Fall 2013. USFSP: 2.3; BOG Area of } \\
\text { Strategic Emphasis }\end{array}$ \\
\hline $2013-2014$ & M & 52.0301 & M.S. in Accounting & $\begin{array}{l}\text { Builds on strength of Bachelors program and } \\
\text { meets community need. Initial enrollment } \\
\text { planned for Fall 2014. USFSP: 1.2; BOG Area of } \\
\text { Strategic Emphasis }\end{array}$ \\
\hline $2011-2012$ & B & 52.0701 & $\begin{array}{l}\text { MS in Global } \\
\text { Entrepreneurship and } \\
\text { Innovation }\end{array}$ & $\begin{array}{l}\text { More businesses are looking to expand their } \\
\text { business overseas. This major helps graduate } \\
\text { students who aspire to focus on global markets } \\
\text { and want to learn how to introduce their ideas } \\
\text { and innovations to global venture capitalists. } \\
\text { Admitting students in Fall 2014. USFSP: 1.5; } \\
\text { BOG Area of Strategic Emphasis }\end{array}$ \\
\hline
\end{tabular}

College of Education

\begin{tabular}{|l|l|l|l|l|}
\hline $2011-2012$ & S & 13.0101 & Ed.S. in Education & $\begin{array}{l}\text { Planned concentrations in leadership, literacy, } \\
\text { ESOL, special education, math and science. } \\
\text { Begin admitting candidates in Fall 2012. USFSP: } \\
\text { 1.2. Only Math/Science/ ESOL have BOG } \\
\text { Critical Needs Designation }\end{array}$ \\
\hline $2011-2012$ & M & 13.1311 & $\begin{array}{l}\text { MAT in Middle Grades } \\
\text { Math Teacher Education }\end{array}$ & $\begin{array}{l}\text { Focus on digital math. To begin admitting } \\
\text { candidates in Fall 2012. USFSP: 1.2; BOG } \\
\text { Critical Needs Designation }\end{array}$ \\
\hline $2010-2011$ & M & 13.1311 & $\begin{array}{l}\text { MS in Middle School } \\
\text { Math }\end{array}$ & $\begin{array}{l}\text { Aimed at middle school math teachers who } \\
\text { have already earned a grad certificate in this } \\
\text { area. Begin admitting candidates in Fall 2011. } \\
\text { USFSP: 1.2; BOG Critical Needs Designation }\end{array}$ \\
\hline & M & 13.1316 & $\begin{array}{l}\text { MAT in Middle Grades } \\
\text { Science Education }\end{array}$ & $\begin{array}{l}\text { To begin admitting candidates in Fall 2012. } \\
\text { USFSP: 1.2; BOG Critical Needs Designation }\end{array}$ \\
& & & \\
\hline
\end{tabular}




\begin{tabular}{|c|c|c|c|c|}
\hline \multicolumn{5}{|c|}{ USF SARASOTA-MANATEE } \\
\hline $\begin{array}{l}\text { Proposed Date of } \\
\text { Submission to } \\
\text { University Board of } \\
\text { Trustees } \\
\end{array}$ & $\begin{array}{l}\text { Program } \\
\text { Level } \\
(\mathrm{B}, \mathrm{M}, \mathrm{D})\end{array}$ & $\begin{array}{l}\text { 6-Digit } \\
\text { CIP } \\
\text { Code }\end{array}$ & $\begin{array}{l}\text { Program Title or } \\
\text { Degree Designation }\end{array}$ & $\begin{array}{c}\text { Comments } \\
\text { (Including Proposed Implementation } \\
\text { Date) }\end{array}$ \\
\hline Fall 2011 & B & 01.0303 & Aquaculture & $\begin{array}{l}\text { Fall 2012: USF Sarasota-Manatee will be } \\
\text { pursuing four-year programs to include } \\
\text { freshmen and sophomores }\end{array}$ \\
\hline Fall 2012 & M & 13.0501 & $\begin{array}{l}\text { Educational } \\
\text { Technology }\end{array}$ & Fall 2013 \\
\hline Fall 2011 & B & 13.1206 & B.S. in Education & $\begin{array}{l}\text { Fall 2012: USF Sarasota-Manatee will be } \\
\text { pursuing four-year programs to include } \\
\text { freshmen and sophomores }\end{array}$ \\
\hline Fall 2012 & B & 19.0799 & Generational Studies & $\begin{array}{l}\text { Fall 2013: USF Sarasota-Manatee will be } \\
\text { pursuing four-year programs to include } \\
\text { freshmen and sophomores }\end{array}$ \\
\hline Fall 2010 & B & 30.1801 & $\begin{array}{l}\text { Interdisciplinary } \\
\text { Natural Sciences }\end{array}$ & $\begin{array}{l}\text { Fall 2011: USF Sarasota-Manatee will be } \\
\text { pursuing four-year programs to include } \\
\text { freshmen and sophomores }\end{array}$ \\
\hline Fall 2011 & M & 44.0000 & $\begin{array}{l}\text { Human \& Geriatric } \\
\text { Services }\end{array}$ & Fall 2012 \\
\hline Fall 2010 & M & 52.0901 & $\begin{array}{l}\text { Hospitality } \\
\text { Management }\end{array}$ & Fall 2011 \\
\hline Fall 2010 & B & 51.0201 & $\begin{array}{l}\text { Communication } \\
\text { Sciences Disorders }\end{array}$ & $\begin{array}{l}\text { Fall 2011: USF Sarasota-Manatee will be } \\
\text { pursuing four-year programs to include } \\
\text { freshmen and sophomores }\end{array}$ \\
\hline Fall 2011 & M & 52.1005 & $\begin{array}{l}\text { Human Resource } \\
\text { Development }\end{array}$ & $\begin{array}{l}\text { Fall 2012: USF Sarasota-Manatee will be } \\
\text { pursuing four-year programs to include } \\
\text { freshmen and sophomores }\end{array}$ \\
\hline
\end{tabular}




\begin{tabular}{|c|c|c|c|c|}
\hline \multicolumn{5}{|c|}{ USF POLYTECHNIC } \\
\hline $\begin{array}{l}\text { Proposed Date of } \\
\text { Submission to } \\
\text { University Board } \\
\text { of Trustees }\end{array}$ & $\begin{array}{c}\text { Program } \\
\text { Level } \\
(\mathrm{B}, \mathrm{M}, \mathrm{D})\end{array}$ & $\begin{array}{l}\text { 6-Digit } \\
\text { CIP } \\
\text { Code }\end{array}$ & $\begin{array}{c}\text { Program Title or } \\
\text { Degree Designation }\end{array}$ & $\begin{array}{c}\text { Comments } \\
\text { (Including Proposed Implementation } \\
\text { Date) }\end{array}$ \\
\hline 2011 & B & 14.1701 & $\begin{array}{l}\text { Manufacturing } \\
\text { Engineering }\end{array}$ & \multirow{12}{*}{$\begin{array}{l}\text { Degrees will not be offered until completion of } \\
\text { SACS accreditation and opening of new I-4 } \\
\text { campus site. } \\
\text { USF Polytechnic will be pursuing four-year } \\
\text { programs to include freshmen and sophomores. }\end{array}$} \\
\hline 2011 & B & 15.0603 & $\begin{array}{l}\text { Manufacturing } \\
\text { Engineering } \\
\text { Technology }\end{array}$ & \\
\hline 2012 & M & 14.1701 & $\begin{array}{l}\text { Manufacturing } \\
\text { Engineering }\end{array}$ & \\
\hline 2012 & B & 14.0301 & $\begin{array}{l}\text { Agricultural/Biological } \\
\text { Engineering }\end{array}$ & \\
\hline 2012 & B & 50.0706 & $\begin{array}{l}\text { Digital Arts/Digital } \\
\text { Design }\end{array}$ & \\
\hline 2012 & B & 04.0201 & Architecture & \\
\hline 2012 & B & $x x \cdot x x x x$ & $\begin{array}{l}\text { Communication } \\
\text { Sciences and } \\
\text { Technologies }\end{array}$ & \\
\hline 2012 & $\mathrm{~B}, \mathrm{M}$ & $x x . x x x x$ & $\begin{array}{l}\text { Integrated STEM } \\
\text { Education }\end{array}$ & \\
\hline 2012 & $\mathrm{~B}, \mathrm{M}$ & $x x \cdot x x x x$ & $\begin{array}{l}\text { Technology Mediated } \\
\text { Learning }\end{array}$ & \\
\hline 2012 & B & $x x \cdot x \times x x$ & $\begin{array}{l}\text { Interdisciplinary } \\
\text { Engineering }\end{array}$ & \\
\hline 2012 & B & $x x \cdot x x x x$ & Design & \\
\hline 2012 & B & $x x \cdot x x x x$ & $\begin{array}{l}\text { Forensic Science } \\
\text { Studies }\end{array}$ & \\
\hline
\end{tabular}




\section{Windows of Opportunity/Unique Challenges}

(If the university has been presented with one or more unique opportunities that have not been included in prior plans but which will receive particular attention during this year, those opportunities should be presented here. Additionally, if the university expects to face a unique challenge in the coming year(s), that should be noted.)

\section{System Collaboration Opportunities:}

- Research Opportunities - Regional Economic Drivers: As one of the leading research universities in the State of Florida, the University of South Florida System contributes significantly to the state's economy, evident by its $\$ 3.2$ billion economic impact on the region. With the system's doctoral granting research university (i.e., USF Tampa) located in a key metropolitan area of Florida, combined with the distinctive locations of the member institutions in surrounding areas covering the Tampa Bay region, the USF System is positioned to strategically meet the needs and demands of the region and continue to contribute to regional and state economy.

- Education and Learning Opportunities - Educated Workforce: One of the unique opportunities for USF is forging a collaborative system of interdependent institutions that plays a significant role in furthering high quality education and first-class research while facilitating new job creation and economic growth for the State of Florida. The system advantages include: greater diversity in educational opportunities and student access; further development of a highly skilled workforce; wider promotion of economic prospects and enhanced growth and development; and better placement in the global economy.

\section{System Challenges:}

- System Collaboration Challenges: The University of South Florida System comprises four institutions: USF Tampa classified by the Carnegie Foundation in the highest basic category - doctoral granting research university with very high research activity; and the three distinctive master's level campuses of USF St. Petersburg, USF Sarasota-Manatee, and USF Polytechnic. As mandated by the Florida State Legislature, institutional members of the USF System are fiscally autonomous and are required to pursue separate accreditation. All four institutions have distinct missions and their own detailed strategic plans approved by the USF Board of Trustees. Each regional institutions/campus will have its own Integrated Postsecondary Education Data Systems (IPEDS) number, will report separately to the National Center for Education Statistics, and will be differentially classified by the Carnegie Foundation for the Advancement of Teaching. The system-wide reporting to the Board of Governors and other agencies will be developed and coordinated through the Office of Decision Support.

- Student - Faculty Ratios Challenges: A major challenge facing the USF System is to enhance the student to faculty ratio. The USF System currently has 27 students per faculty member, which is much higher than the 18 students to faculty average ratio for institutions with similar Carnegie classification, and higher than the average of 22 for the whole Florida SUS system. The USF System is also at a competitive disadvantage when compared with similar institutions across the country. These poor ratios hinder many programmatic initiatives and present significant challenges to improving student success. Strategic realignments in graduate and undergraduate education across the system and the hiring of faculty in high-demand, targeted fields will help to some extent but will not resolve this issue.

- Space and Infrastructure Challenges: There is a need to develop the infrastructure at the USF System for instructional purposes and research activities. Much of the infrastructure is in need of maintenance and new buildings are required to serve the needs of our students and communities. Each campus is faced with considerable challenges to meet the demands for program delivery and student support and faculty research. Instructional and research laboratories are in short supply and classroom construction has not kept pace with the rapid increase in students as the USF System has sought to meet the growing demand for access. 
Tuition Differential Proposal for 2010-2011

\section{University: University of South Florida}

\section{Effective Date}

University Board of Trustees Approval Date:

Implementation Date (month/year):

June $16^{\text {th }} 2010$

August 2010

\section{Purpose}

Describe the overall purpose of the tuition differential at this institution and the aspects of undergraduate education the funds are intended to improve.

\section{Campus or Center Location}

1. Increase undergraduate course offerings

2. Improve graduation rates

3. Increase the percentage of undergraduate students who are taught by full-time faculty

4. Decrease student-faculty ratios

5. Improve the efficiency of the delivery of undergraduate education through academic advisement and counseling 6. Reduce the percentage of students who graduate with excess hours
Campus or Center Location to which the Tuition Differential fee will apply. (If the entire university, indicate as such.)
The entire University of South Florida System (Tampa, St. Petersburg, Sarasota-Manatee, and Polytechnic)

\section{Undergraduate Course(s)}

Course(s). (If the tuition differential fee applies to all university undergraduate courses, indicate as such. If not, also provide a rationale for the differentiation among courses.)

Tuition differential will apply to all undergraduate courses offered by the USF system

\section{Current Base Tuition and Tuition Differential Fee}

Current (2010-11) Undergraduate Base Tuition per credit hour:

Current Undergraduate Tuition Differential per credit hour:
$\$ 95.67$

USF Tampa: $\$ 22.00$

USF St. Petersburg: $\$ 12.80$

USF Sarasota-Manatee: $\$ 12.80$

USF Polytechnic: $\$ 12.80$

\section{Proposed Increase in the Tuition Differential Fee}

Percentage tuition differential fee increase (calculated as a percentage of the sum of base tuition plus tuition differential):

$\$$ Increase in tuition differential per credit hour: $\$$ Increase in tuition differential for 30 credit hours:
$7 \%$

See individual USF institution plans See individual USF institution plans 


\section{Projected Differential Revenue Generated and Intended Uses}

Incremental differential fee revenue generated in 2010-11 (projected):

USF System: $\$ 6,349,677$

Total differential fee revenue generated in 2010-11

(projected):

USF System: $\$ 15,536,285$

Seventy percent $\mathbf{( 7 0} \%)$ of the total differential revenue generated must be used for undergraduate education. The total estimated amount to be spent on undergraduate education is $\$ 10,875,399$.

Describe in detail the initiative(s) and the estimated expenditure(s) for each:

\section{USF Tampa}

a. Increase course offerings $(\$ 884,480)$

b. Improve graduation rates $(\$ 686,966)$

c. Increase the percentage of undergraduate students who are taught by full-time faculty $(\$ 3,481,076)$

d. Decrease student-faculty ratios $(\$ 3,900,193)$

e. Improve the efficiency of the delivery of undergraduate education through academic $(\$ 682,148)$

f. advisement and counseling

\section{USF St. Petersburg}

a. Support ongoing commitments to faculty and staff hired in 2009-10 $(\$ 250,000)$

b. Support for 2 additional faculty members in the sciences, specifically biochemistry, genetics, to provide badly needed courses for USFSP pre-health/health sciences students. Currently, students must take these courses elsewhere and USFSP cannot assure robust assessment of student learning outcomes for courses taken at other institutions. In addition, funds will be used to support the new courses taught in the first year (equipment, supplies, staff support) $(\$ 200,000)$

c. Support for additional academic advisors, support staff and tutors. Our current ratio is 487:1. This is not in keeping with best practice in higher education, particularly for USFSP's student demographic profile (with large numbers of students needing more academic advising help. The USFSP Academic Success Center is one of only three SUS institutions that is accredited by the College Learning and Reading Association. This is a measure of its quality and effectiveness. However, it is understaffed for the increasing number of students that it serves $(\$ 160,000)$

d. Additional support for the Office of Registration and Records support staff to enhance student services and allow some evening hours. This office is a "first line" office for students seeking information on their degree progress and for scheduling of courses. The technology in the office is outdated and needs updating, particularly with regard to the course catalogs. $(\$ 90,000)$

\section{USF Sarasota-Manatee}

a. Increase course offerings

\section{USF Polytechnic}

a. Increase course offerings.

b. Improve graduation rates through timely information on student progress.

c. Improve advising/counseling to enhance the delivery of undergraduate education. 
Thirty percent (30\%) of the total differential revenue generated must be used for undergraduate students who have financial need. Total estimated amount to be spent on financial need is $\$ 4,660,885$. If private sources are to be used, then the estimated amount of private dollars to be raised to offset the fee revenue is $\$ 0$.

Describe in detail the initiative(s) and the estimated expenditure(s) for each:

1. We will continue to target our need based grant awards to students who are paying the differential charges. Total expenditures: \$3,495,664

2. Because we continue to experience an increase in FAFSA filers who have need, the differential revenue will prevent dilution of the need based funds that are being awarded to an increasing number of students. Total expenditures: $\$ 1,165,221$

\section{Monitoring}

Indicate how the university will monitor the success of the tuition differential fee. Provide specific performance metrics that will be used. Also, point out any metrics that are different from the prior year and any prior year metrics that are no longer listed.
1. Freshman retention rate.

2. Six-year graduation rate for FTICs.

3. Three-year graduation rate for transfer students with AA degree.

4. Student to advisor ratio.

5. Student to faculty ratio.

\section{Performance Measure Status}

What is the institution's plan for improving performance on the identified measure(s)? Show initial/baseline data starting with the year before each metric was identified, the goal for each metric, time frame for achieving the goal, and where the institution is now in relation to the goal if not in the initial year.
See individual USF institution report for specific plan's on improving performance in the above outlined measures. 


\section{Tuition Differential Supplemental Information}

Provide the following information for the 2009-2010 academic year.

\section{9-2010 - 70\% Initiatives (List the initiatives} provided in the 2009-10 tuition differential request.)

\section{USF Tampa:}

a. Increase course offerings

b. Improve graduation rates

c. Increase the percentage of undergraduate students who are taught by faculty

d. Decrease student-faculty ratios

e. Improve the efficiency of the delivery of undergraduate education through academic advisement and counseling

\section{USF Health:}

a. Increase the percentage of undergraduate students who are taught by faculty

\section{University Update on Each Initiative}

The $70 \%$ collected to be used to enhance undergraduate education was allocated to hiring new professors, instructors, and academic advisors.
USF Health offers only two undergraduate programs: one in the College of Nursing and one in the College of Medicine. Differential revenue is being used in support of reducing the student/faculty ratio in clinical experiences. Both full-time faculty and adjunct instructors are currently supported. The College of Public Health (COPH) does not have undergraduate programs. However, $\mathrm{COPH}$ offers undergraduate classes that are part of the minor in public health and other general service courses for the university. Revenue from these classes is being used to support the salary of adjunct instructors. These funds have allowed USF Health to support the existing level of undergraduate adjunct instructors and therefore maintain/increase the number of undergraduate course offerings at a time of continued base budget reductions. The total expenditure includes some carry forward funds and thus exceeds the tuition differential revenue.

The $70 \%$ collected to be used to enhance undergraduate education was allocated to hiring adjunct instructors to teach undergraduate courses, and buying news services from a local news bureau in support of undergraduate classes.

c. Improve advising/counseling to enhance the delivery of undergraduate education

\section{USF Sarasota-Manatee:}

a. Increase course offerings

\section{USF Polytechnic:}

a. Increase course offerings

b. Increase the percentage of undergraduate students who are taught by faculty

c. Decrease student-faculty ratios
The $70 \%$ collected to be used to enhance undergraduate education was allocated to hiring adjunct instructors to teach undergraduate courses.

The $70 \%$ collected to be used to enhance undergraduate education was allocated to hiring faculty to teach undergraduate courses. 


\begin{tabular}{|c|c|}
\hline \multicolumn{2}{|c|}{ Additional Detail, where applicable } \\
\hline $\begin{array}{l}\text { Number of Faculty Hired or Retained (funded } \\
\text { by tuition differential): }\end{array}$ & 63 \\
\hline $\begin{array}{l}\text { Number of Advisors Hired or Retained (funded } \\
\text { by tuition differential): }\end{array}$ & 10 \\
\hline $\begin{array}{l}\text { Number of Course Sections Added or Saved } \\
\text { (funded by tuition differential): }\end{array}$ & 74 \\
\hline $\begin{array}{c}2009-2010-30 \% \text { In itiatives (List the initiatives } \\
\text { provided in the 2009-10 tuition differential } \\
\text { request.) }\end{array}$ & University Update on Each Initiative \\
\hline $\begin{array}{l}\text { A portion of the } 30 \% \text { of the differential fee } \\
\text { revenue (approx. } \$ 200,000 \text { ) will be held for USF } \\
\text { to provide grant funding for students whose } \\
\text { families experience changes in their financial } \\
\text { situation. }\end{array}$ & Only $\$ 4,000$ has been used from this fund as of this date. \\
\hline $\begin{array}{l}\text { The remaining amount would be awarded to } \\
\text { eligible continuing students (as defined above) } \\
\text { in an effort to address some of the unmet need. }\end{array}$ & $\begin{array}{l}\text { The differential funding increase resulted in funding for } \\
577 \text { additional students, or an increase of almost sixteen } \\
\text { percent. }\end{array}$ \\
\hline \multicolumn{2}{|c|}{ Additional Information (estimates as of April 30, 2010) } \\
\hline $\begin{array}{l}\text { Unduplicated Count of Students Receiving at } \\
\text { least one Tuition Differential-Funded Award: }\end{array}$ & 2,171 \\
\hline $\begin{array}{l}\text { \$ Mean (per student receiving an award) of } \\
\text { Tuition Differential-Funded Awards: }\end{array}$ & $\$ 1,043$ \\
\hline $\begin{array}{l}\text { \$ Minimum (per student receiving an award) of } \\
\text { Tuition Differential-Funded Awards: }\end{array}$ & $\$ 181$ \\
\hline $\begin{array}{l}\text { \$ Maximum (per student receiving an award) of } \\
\text { Tuition Differential-Funded Awards: }\end{array}$ & $\$ 4,000$ \\
\hline
\end{tabular}




\section{STATE UNIVERSITY SYSTEM OF FLORIDA}

Tuition Differential Collections, Expenditures, and Available Balances

University: University of South Florida System

Fiscal Year 2009-2010 and 2010-11

\section{University Tuition Differential}

Budget Entity: 48900100 (Educational \& General)

SF/Fund: 2 164xxx (Student and Other Fees Trust Fund)

Estimated Actual*

2009-10

\section{Balance Forward from Prior Periods}

Balance Forward

$\begin{array}{r}\$ 87,769 \\ 0 \\ \hline \$ 87,769\end{array}$

Beginning Balance Available:

\section{$\underline{\text { Receipts / Revenues }}$}

Tuition Differential Collections

Interest Revenue - Current Year

Interest Revenue - From Carryforward Balance

Total Receipts / Revenues:

\section{Expenditures}

Salaries \& Benefits

Other Personal Services

Expenses

Operating Capital Outlay

Student Financial Assistance

Expended From Carryforward Balance

${ }^{* *}$ Other Category Expenditures

Total Expenditures:

Ending Balance Available:
$\$ 7,553,995$

15,298

$\begin{array}{r}0 \\ \hline \$ 7,569,293\end{array}$

$\$ 4,896,330$

216,752

4,400

0

$2,264,551$

0

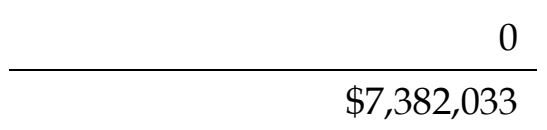

$\$ 275,029$
Estimated

2010-11
$\$ 275,029$

$\$ 275,029$

$\$ 15,536,285$

31,701

0

$\$ 15,567,986$

$\$ 10,433,401$

651,890

0

40,000

$4,660,885$

5,561

$\$ 15,791,737$

$\$ 51,278$

*Since the 2009-10 year has not been completed, provide an estimated actual.

**Provide details for "Other Categories" used. 
Enrollment Plan Proposal (May need to be submitted later than the rest of the Work Plan)

\begin{tabular}{|c|c|c|c|c|c|c|c|c|}
\hline $\begin{array}{c}\text { For entire } \\
\text { institution }\end{array}$ & Funded & Estimated & Funded & Estimated & Estimated & Estimated & Estimated & $\begin{array}{c}\text { 5-Year } \\
\text { Proibeted }\end{array}$ \\
\hline FTE & 2009-10 & 2009-10 & 2010-11 & 2010-11 & 2011-12 & 2013-14 & $2015-16$ & $\begin{array}{c}\text { Average } \\
\text { Annual } \\
\text { Growth Rate }\end{array}$ \\
\hline $\begin{array}{l}\text { FL Resident } \\
\text { Lower }\end{array}$ & 9,378 & 9,174 & 9,378 & 9,275 & 9,284 & 9,497 & 9,685 & $0.9 \%$ \\
\hline $\begin{array}{l}\text { FL Resident } \\
\text { Upper }\end{array}$ & 13,361 & 14,365 & 13,361 & 14,828 & 15,326 & 16,307 & 17,334 & $3.4 \%$ \\
\hline $\begin{array}{l}\text { FL Resident } \\
\text { Grad I }\end{array}$ & 3,682 & 4,018 & 3,682 & 4,089 & 4,208 & 4,529 & 4,831 & $3.6 \%$ \\
\hline $\begin{array}{l}\text { FL Resident } \\
\text { Grad II }\end{array}$ & 852 & 894 & 852 & 959 & 1,007 & 1,133 & 1,316 & $7.4 \%$ \\
\hline $\begin{array}{l}\text { Total FL } \\
\text { Resident }\end{array}$ & 27,272 & 28,454 & 27,272 & 29,152 & 29,825 & 31,465 & 33,167 & $2.8 \%$ \\
\hline $\begin{array}{l}\text { Non-res } \\
\text { Lower }\end{array}$ & & 338 & & 351 & 371 & 412 & 453 & $5.8 \%$ \\
\hline $\begin{array}{l}\text { Non-res } \\
\text { Upper }\end{array}$ & & 409 & & 423 & 441 & 484 & 532 & $5.2 \%$ \\
\hline $\begin{array}{l}\text { Non-res } \\
\text { Grad I }\end{array}$ & & 466 & & 445 & 475 & 544 & 626 & $8.1 \%$ \\
\hline $\begin{array}{l}\text { Non-res } \\
\text { Grad II }\end{array}$ & & 256 & & 263 & 282 & 329 & 399 & $10.3 \%$ \\
\hline $\begin{array}{l}\text { Total Non- } \\
\text { res }\end{array}$ & & 1,470 & & 1,483 & 1,570 & 1,769 & 2,010 & $7.1 \%$ \\
\hline Total Lower & 9,378 & 9,512 & 9,378 & 9,626 & 9,655 & 9,909 & 10,138 & $1.1 \%$ \\
\hline Total Upper & 13,361 & 14,774 & 13,361 & 15,251 & 15,767 & 16,791 & 17,866 & $3.4 \%$ \\
\hline Total Grad I & 3,682 & 4,484 & 3,682 & 4,534 & 4,683 & 5,073 & 5,457 & $4.1 \%$ \\
\hline Total Grad II & 852 & 1,150 & 852 & 1,222 & 1,289 & 1,462 & 1,715 & $8.1 \%$ \\
\hline Total FTE & 27,272 & 29,924 & 27,272 & 30,635 & 31,395 & 33,234 & 35,177 & $3.0 \%$ \\
\hline
\end{tabular}


University of South Florida-System

SUS Work Plans 2010

\begin{tabular}{|l|c|c|c|c|c|c|c|c|}
\hline $\begin{array}{c}\text { For entire } \\
\text { institution }\end{array}$ & Funded & Estimated & Funded & Estimated & Estimated & Estimated & Estimated & $\begin{array}{c}5 \text {-Year } \\
\text { Projected } \\
\text { Average } \\
\text { Annual } \\
\text { Growth Rate }\end{array}$ \\
\hline \multicolumn{1}{|c|}{ FL Resident } \\
$\begin{array}{l}\text { Medical } \\
\text { Professional } \\
\text { Headcount }\end{array}$
\end{tabular}

\begin{tabular}{|c|c|c|c|c|c|c|c|c|}
\hline \multicolumn{9}{|c|}{ USF Tampa } \\
\hline $\begin{array}{c}\text { For entire } \\
\text { institution }\end{array}$ & Funded & Estimated & Funded & Estimated & Estimated & Estimated & Estimated & \multirow{2}{*}{$\begin{array}{c}5 \text {-Year } \\
\text { Projected } \\
\text { Average } \\
\text { Annual } \\
\text { Growth } \\
\text { Rate }\end{array}$} \\
\hline FTE & 2009-10 & 2009-10 & 2010-11 & 2010-11 & 2011-12 & 2013-14 & 2015-16 & \\
\hline $\begin{array}{l}\text { Total } \\
\text { Lower }\end{array}$ & 8,617 & 8,234 & 8,617 & 8,409 & 8,377 & 8,372 & 8,410 & $0.0 \%$ \\
\hline $\begin{array}{c}\text { Total } \\
\text { Upper }\end{array}$ & 9,999 & 10,516 & 9,999 & 10,878 & 11,212 & 11,826 & 12,270 & $2.6 \%$ \\
\hline $\begin{array}{c}\text { Total } \\
\text { Grad I }\end{array}$ & 2,672 & 2,904 & 2,672 & 2,983 & 3,065 & 3,241 & 3,431 & $3.0 \%$ \\
\hline $\begin{array}{c}\text { Total } \\
\text { Grad II }\end{array}$ & 623 & 952 & 623 & 1,002 & 1,065 & 1,236 & 1,489 & $9.7 \%$ \\
\hline Total FTE & 21,911 & 22,607 & 21,911 & 23,273 & 23,720 & 24,674 & 25,601 & $2.0 \%$ \\
\hline
\end{tabular}


University of South Florida-System

SUS Work Plans 2010

\begin{tabular}{|c|c|c|c|c|c|c|c|c|}
\hline \multicolumn{9}{|l|}{ USF Health } \\
\hline $\begin{array}{c}\text { For entire } \\
\text { institution }\end{array}$ & Funded & Estimated & Funded & Estimated & Estimated & Estimated & Estimated & \multirow{2}{*}{$\begin{array}{c}\text { 5-Year } \\
\text { Projected } \\
\text { Average } \\
\text { Annual } \\
\text { Growth } \\
\text { Rate }\end{array}$} \\
\hline FTE & 2009-10 & 2009-10 & 2010-11 & 2010-11 & 2011-12 & 2013-14 & 2015-16 & \\
\hline Total Lower & 104 & 349 & 104 & 319 & 325 & 329 & 333 & $0.9 \%$ \\
\hline Total Upper & 584 & 875 & 584 & 854 & 897 & 919 & 952 & $2.3 \%$ \\
\hline Total Grad I & 498 & 1,044 & 498 & 985 & 1,038 & 1,220 & 1,377 & $8.0 \%$ \\
\hline Total Grad II & 229 & 198 & 229 & 220 & 224 & 226 & 226 & $0.5 \%$ \\
\hline Total FTE & 1,414 & 2,467 & 1,414 & 2,378 & 2,484 & 2,694 & 2,888 & $4.3 \%$ \\
\hline $\begin{array}{c}\text { Total } \\
\text { Medical } \\
\text { Professional } \\
\text { Headcount }\end{array}$ & 480 & 482 & 480 & 482 & 480 & 480 & 480 & $-0.1 \%$ \\
\hline
\end{tabular}

\begin{tabular}{|c|c|c|c|c|c|c|c|c|}
\hline \multicolumn{9}{|c|}{ USF St. Petersburg } \\
\hline $\begin{array}{c}\text { For entire } \\
\text { institution }\end{array}$ & Funded & Estimated & Funded & Estimated & Estimated & Estimated & Estimated & \multirow{2}{*}{$\begin{array}{c}\text { 5-Year } \\
\text { Projected } \\
\text { Average } \\
\text { Annual } \\
\text { Growth } \\
\text { Rate }\end{array}$} \\
\hline FTE & 2009-10 & 2009-10 & 2010-11 & 2010-11 & 2011-12 & 2013-14 & $2015-16$ & \\
\hline Total Lower & 657 & 845 & 657 & 845 & 861 & 893 & 925 & $1.9 \%$ \\
\hline Total Upper & 1,486 & 1,647 & 1,486 & 1,648 & 1,648 & 1,650 & 1,652 & $0.0 \%$ \\
\hline Total Grad I & 227 & 267 & 227 & 266 & 268 & 272 & 277 & $0.8 \%$ \\
\hline Total Grad II & - & - & - & - & - & - & - & - \\
\hline Total FTE & 2,370 & 2,759 & 2,370 & 2,759 & 2,777 & 2,815 & 2,854 & $0.7 \%$ \\
\hline
\end{tabular}




\begin{tabular}{|c|c|c|c|c|c|c|c|c|}
\hline \multicolumn{9}{|c|}{ USF Sarasota-Manatee } \\
\hline $\begin{array}{c}\text { For entire } \\
\text { institution }\end{array}$ & Funded & Estimated & Funded & Estimated & Estimated & Estimated & Estimated & \multirow{2}{*}{$\begin{array}{c}5-\text { Year } \\
\text { Projected } \\
\text { Average } \\
\text { Annual } \\
\text { Growth } \\
\text { Rate } \\
\end{array}$} \\
\hline FTE & 2009-10 & 2009-10 & 2010-11 & 2010-11 & 2011-12 & 2013-14 & 2015-16 & \\
\hline Total Lower & - & 32 & - & - & - & - & - & - \\
\hline Total Upper & 798 & 982 & 798 & 1,048 & 1,095 & 1,196 & 1,306 & $4.9 \%$ \\
\hline Total Grad I & 182 & 164 & 182 & 174 & 182 & 199 & 217 & $4.9 \%$ \\
\hline Total Grad II & - & - & - & - & - & - & - & - \\
\hline Total FTE & 980 & 1,179 & 980 & 1,223 & 1,277 & 1,395 & 1,523 & $4.9 \%$ \\
\hline
\end{tabular}

\begin{tabular}{|c|c|c|c|c|c|c|c|c|}
\hline \multicolumn{9}{|c|}{ USF Polytechnic } \\
\hline $\begin{array}{c}\text { For entire } \\
\text { institution }\end{array}$ & Funded & Estimated & Funded & Estimated & Estimated & Estimated & Estimated & \multirow{2}{*}{$\begin{array}{c}\text { 5-Year } \\
\text { Projected } \\
\text { Average } \\
\text { Annual } \\
\text { Growth } \\
\text { Rate } \\
\end{array}$} \\
\hline FTE & 2009-10 & 2009-10 & 2010-11 & 2010-11 & 2011-12 & 2013-14 & 2015-16 & \\
\hline Total Lower & - & 52 & - & 53 & 92 & 315 & 470 & $157.4 \%$ \\
\hline Total Upper & 494 & 754 & 494 & 823 & 915 & 1,200 & 1,686 & $21.0 \%$ \\
\hline Total Grad I & 103 & 105 & 103 & 126 & 130 & 141 & 155 & $4.6 \%$ \\
\hline $\begin{array}{c}\text { Total Grad } \\
\text { II } \\
\end{array}$ & - & - & - & - & - & - & - & - \\
\hline Total FTE & 597 & 912 & 597 & 1,002 & 1,137 & 1,656 & 2,311 & $26.1 \%$ \\
\hline
\end{tabular}

